\title{
Seismic Relationships
}

\author{
Mary Farrell
}

INTERSUBJECTIVE RELATIONAL PSYCHOTHERAPIST, AUCKLAND

\begin{abstract}
This paper considers the dangerous and heated issues that often underlie outwardly happy relationships. Just as the earth can be unpredictable and smouldering under its calm surface, many relationships between couples have deep fissures that bubble up with unexpected force, often in the consulting room. I present a case study of one such couple and consider the parts played by unrealistic expectation, idealisation, denigration, previous hurts and fractures, and cultural background. I also illustrate the paper with snippets from the American TV series Mad Men, looking particularly at Don and Betty Draper's marriage. Don has a false identity, both literally and metaphorically, and the facts of his earlier life, including his name, are completely unknown to his wife. My premise is that when most couples become attached, it can be an attachment based on primarily unconscious needs and expectations of each other, especially when they have explored and divulged very little. Our role as psychotherapists is to help each member of a couple begin to share their inner lives while maintaining hope that their partner will not use the information shared as a weapon against them.
\end{abstract}

\section{Waitara}

E aro ana tēnei tuhinga ki ngā kaupapa morearea, hahana hūnaia ai e te whakaatanga manahau i rō noho tahitanga a te tokorua. Pērā i te matawhatiwhati o Papatuanuku, he maha ngā whakararu noho puku nohonga à tokorua pahū ake ai i roto i te rūma akoako. E horaina atu ana he mātai takitahi o tētahi tokorua rite ki tēnei ka whakaaro i ngā wāhanga whai wāhi atu ki ngā autāia rerekē, monoa, pēhitanga, mamae inamata me te ahurea. Ka whakaatahia hoki i roto i te tuhinga ètahi maramara kōrero o te Pouaka Whakaata Amerikana Mad Men, aronui atu ki te noho moehanga o Don rāua ko Betty Draper. Ā tuhi, ā kupu whakarite he teka te tuakiri o Don, ā kore kore ana i mōhiotia ngā meka o tōna whakatipuranga, me tōna ingoa e tōna hoa wahine. E kī ana au, inā piritahi he tokorua, he whakapiringa pupū ake ai tēnei mai i ngā wawata me ngā hiahia rehu tētahi ki tētahi, inarā kāre nei e taki mōhio pai ki a rāua anō, à, taki noho puku ai. Ko tā tātou, tātou ngā kaiwhakaora hinengaro mahi, he āwhina i ngā tokorua nei ki te taki whakaatu i ō rāua kare ā roto ki a rāua anō me te mau whakaaro kāre te hoa rangatira e whakamahi i ēnei kōrero hai werohanga atu.

Farrell, M. (2015). Seismic relationships. Ata: Journal of Psychotherapy Aotearoa New Zealand, 19(2), 128-136. DOI:10.9791/ajpanz.2015.12 ( $)$ New Zealand Association of Psychotherapists Inc. 
Keywords: relationships; Mad Men; Gottman; couple therapy; identity

In this article, I look at the pre-conscious and unconscious processes that cause havoc in many relationships, especially the ones that present in psychotherapy consulting rooms. I believe that projection and longing predominate, especially at the beginning of relationships, when there is so little real knowledge and so much room for idealisation of the other. When the idealisation starts to fade and reality is more evident, that here are just two ordinary human beings with frailties, faults, and self-interest, disappointment and criticism often set in, causing the shifting plates of the unconscious to start to crack and fissure and allowing destructive, primitive forces to flare up. For the sake of simplicity in exploring the effects of early dynamics on later relationships, this article is written as if all long-term relationships are heterosexual. Similar and different dynamics are likely to play out in same-sex relationships but this is outside the scope of this article.

When I was at university in 1969 , two heart-breaking ballads were popular, both to do with excessive expectation, inadequacy, and disappointment, and both sung by men and addressed to women. One of them was "The stranger song”, by Leonard Cohen (Cohen, 1967), the other Bob Dylan's “It ain't me Babe” (Dylan, 1964). Dylan's words offer much to reflect on in regards to the difficulty of maintaining intimate relationships.

\author{
You say you're lookin' for someone \\ Who's never weak but always strong \\ To protect you an' defend you \\ Whether you are right or wrong \\ Someone to open each and every door \\ But it ain't me, babe
}

As Dylan's (1964) lyrics suggest many of us expect a parental, unconditional, loyal, admiring, and protective love from our partners, even though we may not be consciously aware of our longing. Who other than perfect parents would be "never weak, but always strong" and protect and defend us no matter what? Cohen's (1967) song includes the line "I told you when I came I was a stranger"; so many women feel that way about the fathers they never really knew and go on to blame their partners for a lack of involvement and emotional unavailability, for remaining the strangers they always were. Many of us had imperfect parents, and clinical work suggests that many long for partners who can somehow correct the emotional deficits, fill the empty spaces in our self-esteem, and give us what was not given in our families of origin.

Many people on their marriage day have no real idea who the other person is. Beguiling physical appearance and ideals of perfection permeate the whole idea of the wedding day. The bride in the white, lace, flowing gown walks down the aisle, veiled and adorned with flowers, given by the loving and protective father to the young, handsome, adoring groom who is being trusted to continue to care for her.

Below I use three examples from the seven-season AMC American TV series Mad Men (Weiner, 2007). The title refers to the advertising executives who worked on Madison Avenue 
in New York in the last decades of the 2oth century. It begins in the early 5os, before equal rights in the US, before the women's liberation movement had even been thought of, when women were secretaries or nurses if they were lucky enough to be employed at all. Men were regarded as successful if they radiated confidence and capability and provided wealth and "wellbeing" for their families. Most married women would have fallen into the category of what we might now call "the surrendered wife" - in other words, she gave birth to gorgeous babies, cooked, cleaned, made sex as pleasurable as she could for her husband, and made sure she had her make-up on and the dinner on the table when he got home from a hard day's work. In advertising, then as now, values were shallow and focused on appearance and persuasion. Here's how we see Betty and Don (Weiner, 2007, Season 1, Episode 3) - the perfect 5 os couple:

Betty is a perfect dream, walking down the stairs on Valentine's evening like Grace Kelly. Don is the epitome of the worldly, handsome, successful man. All is as it should be in terms of romance and glamour. Betty recognises an old friend from her modelling days, Juanita, who is on the arm of a much older, wealthy looking man - there is a brief conversation and they leave. When Betty innocently expresses surprise to Don that Juanita has chosen such an unlikely partner, Don tells Betty that her friend is a "party girl", a polite term for a prostitute. "How do you know that?" asks Betty. "How stupid do you think I am?" asks Don, with a knowing smile. Already, we sense a disparity between them in terms of life experience. There is an implication that Don has known quite a few "party girls" and a belittling of Betty's lack of worldliness. When Betty asks about the plans for the evening, Don suggests room service. We get a sense of Betty's disappointment that Don does not want to share the romantic Valentine's dinner she had been expecting and treats her like a party girl instead.

As a parallel to Betty and Don's relationship, I'd like to present a short study of a couple I have worked with for some time. All identifying personal details have been significantly changed to protect their confidentiality.

Giuliana is a stunningly beautiful woman of Mediterranean origin who has lived in New Zealand for some years. She is in her early zos. Stuart is a Kiwi financial executive who has done very well in business. He is in his late 40 . They make a striking couple. Giuliana had an extremely traumatic childhood - her mother is a drug addict and had several partners when Giuliana was a child. There was no permanent family home and she and her mother were often on the move. Her biological father is a European movie star, and has never wanted to have anything to do with her or her mother. After being forced into a paternity test by law, he was made to pay child support until Giuliana was 18 , but has had no contact with her other than this.

By contrast, Stuart had what one might call a fairly stable childhood - his well-off family sent him to the best schools but was emotionally neglectful. Like many New Zealand men, he learned to be capable, athletic, and self-sufficient, and to repress his vulnerability and pain. His mother was autocratic and dominating; early in his life he learned how to avoid her. He has a pack of close male friends and they meet after work, play various sports together, and are inclined to drink a lot of alcohol - they often behave like teenagers.

Stuart pursued Giuliana relentlessly for a year before they married - an expensive affair with all the bells and whistles. She was quite a prize, with a figure to die for and an exquisite face. At first, all went well. The problems emerged when Giuliana became pregnant and was 
extremely fragile and vulnerable, losing weight rather than gaining it, and craving extra attention and care from her husband, who did nothing to adapt to what he saw as "needy behaviour". He was impatient and irritable if she complained and went out with his friends more rather than less.

This pattern threw Giuliana into the centre of her tormenting insecurities - she felt ugly, unlovable, and unwanted. The more she disappeared into her own personal vortex of anguish, the less Stuart wanted her. It became unbearable for her, and she would often leave with no warning to stay with a friend, refusing to answer texts from Stuart asking where she was. She wanted him to feel what she was feeling and to redress the imbalance of power between them, so that he was waiting for her, instead of the other way around.

Although Stuart knew some of her childhood issues, he had no real knowledge of how hellish her life had been and how very alone she had been for most of it, using her beauty as currency to buy love, care, tenderness, and protection from the men who fell in love with her. Her pregnancy brought up all the old fears and horrors - she was no longer able to be the coolest girl in the room - although she tried throughout her pregnancy to conceal her belly and continued to wear the skin-tight pants and high-heeled boots that had become her armour.

Often in therapy, they would row as if they were at home, leaving me to try to calm them both. Giuliana was exquisitely sensitive to any perceived criticism and liable to sob inconsolably for most of the session. Stuart alternated between coldness and incomprehension. He had no idea as to why she was so distressed and would often say, "It's not that bad, is it?" At other times, he would laugh as she sobbed, not in a cruel way, but almost like an indulgent and inept father watching his little girl go through an inexplicable tantrum. I recently come across a wonderfully precise description of the expression I have seen on Stuart's face when witnessing Giuliana's distress. It comes from Catherine Lacey's brilliant debut novel Nobody is Ever Missing:

My husband was staring at me with this brand new look of his - one I had not seen before, but would see much more of in the future. He was looking at me like I was a very nice thing of his that wasn't working quite like it should, like he'd found a defect, a defect that was extremely disappointing because he'd spent a lot of time doing his research and believed he had gotten a thing that was guaranteed against these kind of defects and maybe there was a glitch in the system and he needed to have a professional assess the situation and give him an estimate. (Lacey, 2014, pp.110-111)

Clifford Sager and colleagues, in their paper "The Marriage Contract" (1971), wrote of each partner's expressed and unexpressed, conscious and unconscious concepts of obligations and benefits of the marital relationship. They focussed on the reciprocal aspect of the contract - what each partner expects to give and receive in exchange:

The terms of the contract are determined by the deep needs and wishes that the individual expects the marital relationship to fulfil. It goes without saying that these will include healthy and realistic as well as neurotic and conflictual needs. (p.311) 
There is often limited awareness, and sometimes complete lack of awareness, of one partner's expectations of the other; each partner may assume there is mutual agreement on the terms of his own contract, when in fact, there is not.

Nevertheless, the individual then behaves as if an actual contract existed, and each person was obliged to fulfil its terms. In that event, when significant aspects of the contract cannot be fulfilled, as is inevitable especially when the terms of the contract lie beyond awareness, the disappointed partner may react with rage and depression and provoke marital discord as though a real agreement had been broken. This response is particularly likely to occur when one partner feels he or she has fulfilled his obligations, but the other has not. (Segar et al, 1971, pp. 311-312)

In Stuart and Giuliana's relationship, this is played out over and over again - Giuliana's desperate need for a loving and caring father to be completely and lovingly preoccupied with her is in massive conflict with Stuart's need to have a sweet-natured, competent, and sexually attractive woman ready to greet him with cheerfulness and affection when he comes home from his adventures and endeavours at work and play. He sees his part of the contract - being an excellent financial provider for his wife and children - as being amply fulfilled. Giuliana awarded him the prize of herself and was expecting much more daily appreciation of her gifts than was ever forthcoming once they set up home together. As Sager and colleagues (1971) explained, both partners feel that they have fulfilled their obligations and that the other has not.

I see one of the sources of this problem as being the very limited knowledge many people have of each other when they decide to marry or set up home together. A feeling of knowing the other is often an assumption or a delusion rather than a reality. This is well illustrated in the relationship between Don and Betty Draper in Mad Men. During the first two seasons, we were given clues that Don had a mysterious and complex past life, but it was not until the third season that Betty discovered that she did not even known his real name, let alone any of the circumstances of his traumatic early life and young adulthood. Like Stuart, Betty had a materially privileged but emotionally difficult childhood.

One of the most heart breaking scenes in Mad Men resulted from Betty's discovery of a battered old shoebox holding photos and documents belonging to Dick Whitman - Don's real name (Weiner, 2007, Season 2, Episode 4). Betty confronted Don with the box as he came in from work; he was visibly shaken and, for once, vulnerable. He tells her a little of his past - that he was brought up in extreme poverty and that during his time in the army in Korea was in an accident with the real Don Draper who was blown to pieces right next to him. Their identities were mixed up in the military hospital. Back in the US, he kept the false identity, wanting to escape from his life as Dick Whitman. Betty was horrified by the lie he had been living since before they even met.

It seems to me that at this point Don and Betty had an opportunity to make the superficial facade of their marriage far more meaningful and honest. Don's true identity and vulnerability became transitorily evident and yet the moment passed and nothing was achieved by the revelations. Unfortunately, in both sets of couples, the fictional Don and Betty, and the real Giuliana and Stuart, clinging to fantasy remains the most consistent 
factor - the other is a disappointing failed object, not measuring up to the longed for ideal parent. In David and Jill Scharff's collection, New Paradigms for Treating Relationships, Walton Ehrhardt wrote:

The primary motivations for the relationship were the pursuit of survival, the need to use the other to complete the deficiencies in the sense of self, and above all, the necessity of maintaining a feeling of oneness. Frustration quickly mounted between them as one talked above the other. (Erhardt, 2006, pp.351-352)

Erhadt (2006) wrote of the manifestations that often arise in the consulting room; I am sure many who work with couples will recognise them: "Hurling identical paranoid projections and accusations at one another" and "Alternately presenting a need for the other, as if the other is part of oneself".

Many therapists have the experience of sitting with couples who want to hurt, blame, and shame the other for not measuring up to the idealised image that each has of the other. Lacey again:

There were nights when we argued about something that didn't matter - something that can be summarized as "I believe you are a bit more despicable than me". (2014, p.133)

Sometimes it is hard to understand why some couples refuse to leave the marriage and choose a different life but it is important for us to be aware of the unconscious "ties that bind”. There are several theories of partner selection, and here I am referring to our own culture where partner selection is in our own hands rather than in the hands of the extended family. The most compelling seems to me to be the Imago theory, in other words, that we are attempting, unconsciously, in our selection of a partner to complete the unfinished business of our childhood by gravitating towards those who have a great deal in common with the parent of the opposite sex (Hendrix, 1988). Unfortunately, we often tend to choose a partner with a similar pattern of childhood wounding as ourselves but a different way of dealing with it. So one partner might have a vocal and insistent way of signalling needs and anxieties in order to get them met, and the other may have an avoidant and detached way of dealing with needs and anxieties in order to not be overwhelmed by them. This can often replicate the manner in which the longed for parent related to us. So the ideas of "whinging", "want doesn't get", and "spoilt little bitch" can re-emerge between men and women, with similar wounds inflicted from the other side: "selfish bastard", "cold hearted monster", and "incapable of love".

As clinicians, we often witness and attempt to contain verbally violent protests from the couples we see. Abusive exchanges occur as both partners regress, and come from a place of hurt and powerlessness as they desperately attempt to regain power by intimidating the other.

By the time Season 4 of Mad Men opened (Weiner, 2007), Betty, deeply wounded by learning how much Don had concealed from her has reacted by responding to another man's advances and having a secret of her own. In the third episode, Don is told by a colleague 
that Betty is having an affair with a local politician, Henry Francis. He returns home full of rage, violently hauls Betty out of bed and demands to be told the details. A nasty quarrel ensues and bitter, hateful names are called. Here we can see the escalation of emotions and fury as Don realises the situation has been reversed and it is Betty who now has the advantage. He uses contempt and intimidation to attempt to reclaim his position of power.

John Gottman's work is helpful in thinking about what is most destructive to a relationship. In Seven Principles for Making Marriage Work (2011), he described his research into marriage and divorce in his famous Seattle Love Lab, where volunteer couples agreed to reside and be monitored during the weekend. Their instructions were to go about their daily lives as much as possible while a team of University of Washington researchers observed their interactions and heart rates. Gottman's controversial claim was that he could predict divorce from watching a couple for 24 hours. One of Gottman's best-known ideas is that there are "four horseman of the apocalypse" that will kill off any marriage:

Criticism: stating one's complaints as a defect in one's partner's personality, i.e., giving the partner negative trait attributions. Example: "You always talk about yourself. You are so selfish."

Contempt: statements that come from a relative position of superiority. Contempt is the greatest predictor of divorce and must be eliminated. Example: "You're an idiot." Defensiveness: self-protection in the form of righteous indignation or innocent victim-hood. Defensiveness wards off a perceived attack. Example: "It's not my fault that we're always late; it's your fault."

Stonewalling: emotional withdrawal from interaction. Example: The listener does not give the speaker the usual nonverbal signals that the listener is "tracking" the speaker. (Gottman, 2011)

Gottman (2011) recommended that couples commit to listening, understanding, knowing, and responding to each other better. He also found that while gender differences may contribute to marital problems, they do not cause them, writing that the determining factor in whether both women and men feel satisfied with the sex, romance, and passion in the marriage is the quality of the couple's friendship. Each partner needs to be willing and able to understand the other's different background, experience, point of view, and opinions if a troubled relationship is to start to heal. Finding out about the authentic other, rather than assuming knowledge that is based on myth or idealisation is paramount. And here is where we, as therapists working with couples, can help most. Sager again:

In a surprisingly short time, secrets of the couple from one another become less necessary. The therapist must be sensitive as to how far to go in exposing one spouse to the other, but gradually patients learn not to use as a weapon information learned about their partner's innermost thoughts and fears. (Sager, 1967, p. 142)

We must be patient and careful in helping our couple clients become more of an open book to each other - Sager (1967) recommended sharing dreams and looking at their possible meanings together, as well as bringing out childhood memories and associations. Exploring 
the spoken and unspoken contracts and expectations they have of each other is vital.

The final song I wish to refer to was a huge hit in the early 1970 - Simon and Garfunkel's "Bridge over Troubled Water" (Simon, 1970). So many women in their 20s, as I was when this song came out, long for the selfless hero portrayed in this song: the man who would wish only for our success, comfort us when we are sad and alone, glory in our achievements. In other words, the perfect father. And it goes both ways; many men also long for the perfect mother who will care for them, cook for them, comfort them and satisfy them, celebrate their achievements and empathise with their frustrations. If couples are willing to recognise and explore the turbulent waters of disappointment and frustration that arise when it becomes obvious that the ideal father or mother will be forever elusive, we are well placed to help them build a bridge so they can both cross over to a more honest, realistic view of themselves and each other, able to acknowledge their needs and desires, and accept that some of them can never be met.

\section{References}

Cohen, L. (1967). The stranger song. On Songs of Leonard Cohen. New York, NY: Columbia. Dylan, B. (1964). It ain't me babe. On Another side of Bob Dylan. New York, NY: Columbia.

Erhardt, W. (2006). Couples in narcissistic collusion: Sexual fantasy and acting out. In J. Scharff \& D. Scharff (Eds.), New paradigms for treating relationships. New York, NY: Jason Aronson.

Gottman, J. \& Silver, N. (2011). The seven principles for making marriage work: A practical guide from the country's foremost relationship expert. New York, NY: Barnes \& Noble.

Hendrix, H. (1988). Getting the love you want: A guide for couples. New York, NY: St. Martin's Press.

Lacey, C. (2014). Nobody is ever missing. London, UK: Granta Books.

Sager, C. (1967). The conjoint session in marital therapy. American Journal of Psychoanalysis, $27(2), 139-146$.

Sager, C. J., Kaplan, H. S., Gundlach, R. H., Kremer, M., Lenz, R., \& Royce, J. R. (1971). The marriage contract. Family Process, 10(3), 311-326. doi: 10.1111/j.1545-5300.1971.00311.x

Simon, P. (1970). Bridge over troubled water. On Bridge over troubled water. New York, NY: Columbia.

Weiner, M. (2007). Mad men [Television Series]. Los Angeles, CA: Weiner Bros.

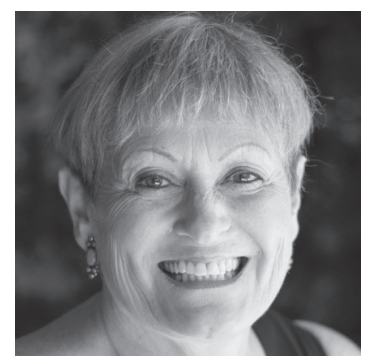

Mary Farrell is an intersubjective relational psychotherapist working in private practice in Titirangi and Mt Eden, Auckland. She studied theatre and fine art for her first degree and worked as a theatre director in the UK for 17 years before training to become a psychotherapist in 1990 . In the UK, she worked for the British Law Society, directing the Counselling Service at the Chester College of Law until she emigrated to New Zealand with her family in 1995. Mary's passion lies in tracing the links between psychotherapy, theatre, film, literature and art. Her book Acts of Trust - Making Sense of Risk, Trust and Betrayal in our Relationships was published 


\section{SEISMiC RELATIONSHips}

by Exisle in 2005, and she has given several illustrated papers to NZAP conferences, branch meetings, forums, and at Elam Art School. Contact details: mary@maryfarrell.co.nz . 